\title{
Management of industrial work practices in improving student competence and satisfaction of the industrial as a partner vocational school
}

\author{
Silvana Wulansari ${ }^{1}$ \\ ${ }^{1}$ Sekolah Menengah Kejuruan Negeri 1 OKU, Indonesia
}

\begin{tabular}{l} 
Article Info \\
\hline Article history: \\
Received Jul $12^{\text {th }}, 2021$ \\
Revised Aug $15^{\mathrm{h}}, 2021$ \\
Accepted Aug $30^{\text {th }}, 2021$ \\
\hline
\end{tabular}

\section{Keyword:}

Management of industrial work practices

Student competence

Satisfaction of the industrial practices

\begin{abstract}
This study describes the planning, implementation, and evaluation of industrial work practices in improving student competence and satisfaction of the industrial world as a working partner of a vocational school. The implementation of industrial work practices is in following the dual system education implementation guidelines. Management of industrial work practices from planning, implementation, and evaluation is still experiencing obstacles. The results of the satisfaction survey show that the competence of students is not in by the needs and work culture of the industry, school supervisors are not maximized in monitoring the development and progress of students in the industry, there are still many students who are not competent in operating computers, the industry assignments to students that are not in following the competence of expertise in their field so that the objectives in competency mapping have not been achieved. School supervisors have not completely informed about the involvement of the industrial world business world in the implementation of industrial work practices. Practical work provides additional knowledge and skills of students so that competency gaps in the mapping of competency skills can be minimized, but these competencies do not yet cover the entire competency gap. The implementation of work practice for 3 (three) months is quite effective, because with this duration students perform certain tasks repeatedly to improve student competence in completing assignments and maximum work results, however, it was still found that students were not responsive enough in other assignments given. The evaluation of industrial work practice management with the analysis that has been carried out so far is quite good, but the follow-up actions have not provided an improvement in the performance of the management team as a whole so that the mismatches keep recurring in the implementation of the next work practice.
\end{abstract}

(C) 2021 The Authors. Published by IICET.

This is an open access article under the CC BY-NC-SA license (https://creativecommons.org/licenses/by-nc-sa/4.0

\section{Corresponding Author:}

Wulansari, S.,

Sekolah Menengah Kejuruan Negeri 1 OKU, Indonesia

Email: silvanabta79@gmail.com

\section{Introduction}

The National Education System Law Number 20 of 2003 in article 15 which is accessed at https://pusdiklat.perpusnas.go.id, explains that vocational education is secondary education that prepares students especially to work in certain fields, while vocational education is higher education that prepares 
students to have a job with certain applied skills at a maximum equivalent to a bachelor's program [1]. [2] argues that vocational education in schools has caused structural problems that lead to a lack of relevance to employment. The government continues to strive to improve the quality of SMK in order to produce more trained middle-level vocational and technicians so that they are able to meet job requirements in the fields of industry, trade and services and are able to work independently to open new jobs and businesses.

Based on Presidential Instruction Number 9 of 2016 which is accessed from jdih.kemenperin.go.id, The government has programmed the revitalization of Vocational High Schools in an effort to improve the quality and competitiveness of Indonesia's human resources. This is in line with the Regulation of the Minister of Industry Number: 03/M-IND/PER/1/2017 concerning the coaching and development of competency-based Vocational High Schools that link and match through collaboration with industry.

The collaboration between the Ministry of Education and Culture and the Indonesian Chamber of Commerce and Industry aims to involve the industrial world and companies in implementing dual system education. Steps taken by SMK in preparing workers who are competent in their fields with a dual system of education, one of which is industrial work practices.

[3] Vocational education still faces qualitative and quantitative equivalence constraints, qualitative equivalence occurs due to the rapid development of technology in industry so that there is a competency gap between vocational high school graduates and the competencies needed in the industrial world, while quantitative equivalence occurs due to an imbalance in the number of jobs in the industrialized world by the amount of educational output looking for work.

[5] competence is a statement of how someone can demonstrate their skills, knowledge and attitudes in the workplace in accordance with Industry standards or according to the requirements set by the workplace (industry). Competence is a combination of knowledge, skills, values and attitudes that are reflected in the habit of thinking and acting. Job competence is the formulation of work ability that includes aspects of knowledge, skills and / or expertise as well as the minimum work attitude that a person must have to occupy a certain position that applies nationally.

Management that is right on target and appropriate in the management of industrial work practices for vocational students plays an important role so that the expected goals can be achieved. Management of industrial work practices [4] is defined as everything related to the management of industrial work practice processes to achieve predetermined goals, both short, medium and long term goals. Industrial work practice management is a series of activities to plan, organize, and evaluate a learning program in schools and in the business world and industry, namely through training and learning in order to improve the competence of skills possessed by students.

The business world and the industrial world are partner institutions that are working partners and have entered into an agreement with SMK both orally and in writing to collaborate with the aim of being a place for implementing practices in order to improve vocational skills. The business world and industry designated by SMK are institutions that have work activities that are in accordance with the majors in the field of expertise of the study program at the Vocational Schools that establish partnerships. The understanding ability obtained from the learning process at school combined with the learning process in industry or in society is an important factor in determining student success. Through a learning process like this, students will systematically experience an increase in knowledge, skills and attitudes in doing their work.

Administration of industrial work practice management and work plans is good enough. It's just that in general, the activities of planning, organizing, controlling, placing, directing, motivating, communicating and making decisions made by management have not been maximized so that activity linkages have not provided effective and targeted benefits for students. Every organization, including schools, has a goal of organizing various resources owned by it so that it will increase student competence and produce graduates who are ready to work. The constraints in the field are that there are still many DUDI who are not yet relevant to existing expertise programs in schools and are able to become a place for student learning practices in accordance with the objectives of industrial work practice and the expected competencies based on the curriculum.

Problems faced in the management of industrial work practices and students, including the understanding of the business world and industry towards this program, namely planning industrial work practices in industrial mapping, there is an inconsistency between skills competencies in schools and work topics or tasks in the business and industrial world. This has an effect on the preparation of industrial work practice programs because it is still found that assignments in practice locations are not in accordance with the existing competencies in their expertise program so that there is dissatisfaction with the business world and industry with student competencies when implementing industrial work practices. 
This condition encourages the authors to conduct research on the management of industrial work practices at SMK Negeri 1 OKU both in planning, implementing, and evaluating industrial work practices, increasing student competence and the satisfaction of the industrial world as partners with the internship program. This research is expected to be able to provide solutions in implementing proper management so as to provide feedback in increasing student competence and satisfaction in the business world of the industrial world.

\section{Method}

The author's case study research was carried out by focusing on the implementation of industrial work practice management at SMK Negeri 1 OKU which was appointed as a case to be studied in depth in terms of increasing student competence as participants and the industrial world as a partner of SMK Negeri 1 OKU.

SMK Negeri 1 OKU which is located on Prof. Ir. Sutami No. 0176 East Baturaja District, is one of the SMKs in Ogan Komering Ulu Regency which provides education in the field of business management and technology studies. This school has 5 (five) expertise programs namely Institutional Financial Accounting, Office Automation and Governance, Online Business and Marketing, Computer and Network Engineering and Multimedia.

Research subjects related to industrial work practices involve school principals, deputy heads of the field of public and industrial relations, industrial work practice coordinators, heads of expertise programs, school supervisors, students as work practice participants, industrial supervisors. The research data were obtained by interviewing, observing, documenting and surveying the satisfaction of business and industry.

Interview techniques, documentation, observation and questionnaires in this study to explore the various obstacles that exist through data collected from research subjects. Existing data are analyzed to find the causes of problems in the management of industrial work practices at SMK Negeri 1 OKU in an effort to improve student competence and satisfaction in the business world of the industrial world so that follow-up improvements can be provided for the management team.

\section{Results and Discussions}

\section{Planning for Industrial Work Practices of SMK Negeri 1 OKU}

Planning for industrial work practices at SMK Negeri 1 OKU begins with compiling an apprenticeship work program which contains the entire planning of industrial work practice activities. Planning starts from mapping the competency of expertise, implementing and / or checking the MoU with the business world and industry, mapping the business world and industry which will become work practice places for students according to the competency of skills that will participate in that period, industrial networking to find out their availability for the number of students and existing competencies, determining school participants and supervisors, and providing provision for students and school supervisors regarding conditions and atmosphere and work procedures in the industry.

Competency skills in Accounting and Financial Institutions, Office Automation and Governance, Computer and Network Engineering as well as Online Business and Marketing which were included in the second wave of industrial work practices which began on October 1, 2020 to December 22, 2020 with 10 students in each skill competency. The business world and industries involved are located in OKU district, namely Bank Sumsel Babel, BPR Baturaja, PDAM, PT Pegadaian, Hypermart Baturaja, OKU Police, OKU Regional Secretariat, Dukcapil, Tourism Office, District Court, PT POS Indonesia, and FIF Baturaja. Students from the four skill competencies of SMK Negeri 1 OKU as practice participants are placed to blend in the mapped business and industrial world. This causes the placement of students in the industry not in accordance with the competencies needed in the industrial world business world that has been mapped by the school.

\section{Implementation of Industrial Work Practices}

The implementation of industrial work practice for three months begins with the handover of students as practical work participants by school supervisors on October 1, 2020 directly to industries that have been from school. At the beginning of the practice, there were industries that provided work implementation briefing to students and some provided direct directions when students were given certain assignments. 
Students do basic work in a specific section of the industry with direct guidance from an industry tutor. This job becomes routine work and other additional tasks that are given in accordance with the existing scope of work. Industry advisers monitor student progress including how they adapt to the work environment and climate. Students begin to understand work procedures in related fields and are able to differentiate between the theory and practice they receive in school.

The results of interviews with the head of the expertise and school guidance program found that there are still industrial practices who give assignments to students that are not in accordance with the competencies in the expertise program, even though the competencies have been mapped according to the industry that is the school's partner. Competency mapping in industry is expected so that students can maximize their competence, except for competencies that have not been received in the 4 th, 5 th and 6 th semester classes. Of course this is a competency gap for students when carrying out work practices. This competency gap is expected to be synchronized with guidance from the industry.

For three months, students understand the importance of self-character and work attitudes in order to be able to socialize in the world of work. Students record their daily attendance while carrying out industrial practice in the attendance sheet attached to the journal. The work they do is recorded every day in the activity agenda by selecting the competencies that have been mapped. This shows the suitability of work and competencies in the expertise program. However, not all competencies that are mapped and should be learned in the industry can be implemented. This is certainly a finding for the school so that it can be followed up for the implementation of the next industrial work practice. The attendance sheet and activity agenda, signed by the industry supervisor as proof that the work is able to be completed by students and their attendance is in accordance with the working hours in the related industry.

School supervisors monitor the development of internship participants by receiving information either directly from industry supervisors or from the participants themselves. There are some students who are still violating the rules at work and were delivered when the school supervisors directly monitored them in November 2020 by submitting a customer satisfaction survey in the form of a questionnaire as an assessment of the school and practice participants. It was during this monitoring that the school supervisor received complete information about the progress of the internship participants.

Towards the end of the industrial work practice, the industry supervisor guides the participants to prepare a final report on the activity. This is one of the duties of industry supervisors, because this report becomes an analysis material for schools in evaluating the results of participant activities. Information about the duties of industrial supervisors and the completeness of assessments is often not clearly conveyed by school supervisors when accompanying students at the start of the practice. This causes industry supervisors to not understand the role of industry regarding the implementation of work practices in accordance with the goals expected by the school. In addition to industry supervisors, students also consult with school supervisors regarding the contents of the report if they experience problems.

The end of work practice activities in the industry, the school supervisors withdrew students on December 22,2020 . The withdrawal process was carried out directly by school supervisors in industry who were partners of SMK Negeri 1 OKU. The industry conveyed the advantages and disadvantages that have been made by students during implementation. After withdrawing participants, students will return to study at school in the 6th (six) semester of January 2021 according to the educational calendar.

\section{Evaluation of Industrial Work Practices}

Evaluation is carried out by representatives of public relations and Industry through the results of industrial work practice reports that are analyzed after completing work practices. The report will be presented by students in semester 6 (six) of class XII. However, due to the current pandemic and not yet permitted by the South Sumatra Provincial Education Office, it will be reconsidered with the principal whether it will continue or be postponed. If this is not possible, then the student's report will be analyzed directly by the school supervisor and the results of the analysis will be submitted to the management team.

Given past experience, the results of the report analysis aim to determine whether the competency mapping of expertise programs can be carried out by industry or only a few are able to guide students according to their competencies. The results of the analysis will be followed up as consideration for planning for further practical work activities. The follow-up will be discussed first with the internship team and submitted to the principal. 
Furthermore, the evaluation is through the results of the assessment from industry supervisors from both technical and non-technical assessments. This assessment is analyzed to check the suitability of the work written on the report with the results of the supervisor's assessment. Assessments with a predicate of less have never been found during work practice, and what often appears is a good predicate.

Further evaluation, namely by analyzing the results of the customer satisfaction survey through a questionnaire given by the school. The results of the questionnaire were recapitulated and followed up to improve and prevent the recurrence of existing discrepancies.

\section{Increasing Student Competence}

Industry supervisors provide an assessment according to the guidelines given by SMK Negeri 1 OKU which consists of technical and non-technical assessments with the predicate Very Good: 86-100, Good: 70-85, Less: $<70$. This assessment is given in accordance with the progress monitored by industry supervisors during the implementation of activities both in terms of attitude (non-technical) and knowledge and skills (technical).

1. Competency Assessment Sheet by the Business and Industry World

Industry supervisors provide an attitude assessment, namely the values of honesty, discipline, hard work, creativity, independence, curiosity, respect for achievement, communicative, environmental care, social care, and responsibility on the attitude assessment sheet. Based on the attitude assessment, in the sixth semester of class XII, the homeroom teacher will check the development of student attitudes while in school and industry.

The school supervisor said that the attitudes of students, especially from the work ethic, began to grow and become better, but there were also those who were not maximally as expected. Technical assessment in the form of knowledge and skills based on the implementation, process and results of real work carried out by students in accordance with the assignments given based on the basic competencies of each expertise program. By doing certain jobs repeatedly for three months, the industry supervisor explained that there was an increase in certain competencies in accordance with the skill competency mapping. These competencies are inputted by industry supervisors for student technical assessments. The values of these attitudes, knowledge and skills were inputted into the E-report in 6th semester by the homeroom teacher.

2. Industrial Work Practice Certificate

Business and industry give certificates to students after completing practical work activities. Still the front sheet of the certificate contains a statement from the industry regarding the implementation of activities with a certain predicate. The back sheet lists the technical assessments with the titles that have been assessed by the industry supervisor. The original certificate is held by the student and a photocopy is submitted to the school through the industrial work practice coordinator.

In fact, the industry is still reluctant to provide certificates according to the format given by schools. They provide a certificate that the student has carried out work practices in the related industry during the specified implementation date only. This is of course a problem that must be resolved so that the purpose of granting a certificate as recognition of student work competence in certain tasks is in accordance with the guidelines for implementing industrial work practices at the Directorate of Vocational Education.

\section{Satisfaction of the Industrial World Business World with the Implementation of Industrial Work Practices of SMK Negeri 1 OKU}

The school management team must evaluate activities carried out related to work practices in the industrialized world of business. This is expected to be able to improve the performance and satisfaction of the business world and industry with the competence of students of SMK Negeri 1 OKU. One of them is by conducting a customer satisfaction survey for the business world and industry in the form of a questionnaire. This survey questionnaire will be further analyzed and become a consideration for future school management work steps. 
1. Recapitulation of Satisfaction Survey Results

The results of the Satisfaction Survey show the industry's assessment of schools and students. There are still many discrepancies that occur regarding the management of industrial work practices in terms of student placement according to their competence, lack of student competence in terms of work attitudes, knowledge and skills in completing a given task, lack of creativity and student response at work, and students have not been able to operate computers properly. good. It was found that there were still many businesses and industries that gave a score of 3 (good), and there was 1 (one) DUDI that gave a score of 2 (enough), namely questions about the placement of students who work practices according to their competence. These findings are recapitulated by the coordinator and submitted to representatives of the field of public relations and industry and followed up with the head of the expertise program during the preparation of the second batch of work practice activity reports.

2. Follow up of Satisfaction Survey Results

The results of the recapitulation of satisfaction survey corrective actions are analyzed to determine the follow-up of improvements so that the actions taken are right on target and effective. Corrective action is monitored by representatives of the public and industry relations sector to monitor the progress of follow-up results. The success of schools in meeting the satisfaction of the industrial world business world will be seen in the next industrial work practice activities with the results of the survey given.

\section{Conclusions}

The management of industrial work practices at SMK Negeri 1 OKU is carried out in accordance with the guidelines for the implementation of dual system education by involving the industrial world in an effort to improve student competence. Management, which starts with planning, implementation and evaluation, is still experiencing problems. This can be seen from the results of the survey on the satisfaction of the business world and industry which stated that the competence of participants who were placed did not match the needs of the industry, the competence of attitudes in obeying the rules and not in accordance with the work culture of the industry, school services in monitoring the development and progress of students in the industry were not optimal, there are still many students who are not competent in operating computers.

Mapping competency skills which is part of planning management, it was found that the industry still has not given assignments to students according to the competence of expertise in their fields so that the objectives in competency mapping have not been achieved. The limited time for student debriefing with the amount of material has not provided a detailed and clear understanding so that students need maximum guidance from school and industry supervisors.

School supervisors have not completely informed about the involvement of the business world and industry as working partners and administrative documents provided in the implementation of industrial work practices so that there are mismatches in the assessment format from schools and the awarding of certificates from the industry. The implementation of industrial work practices provides additional knowledge and skills of students so that the competency gaps that exist in the mapping of skills competencies can be minimized, but these competencies do not yet cover the entire existing competency gaps.

The implementation of industrial work practices with a period of three months is quite effective, because with that duration students perform certain tasks repeatedly so as to increase student competence in completing assignments and maximum work results. However, it was still found that students were not responsive enough in other given assignments. Management evaluation with the analysis carried out so far is quite good, but the follow-up actions have not provided an improvement in the overall performance of the management team so that the discrepancies continue to recur in subsequent work practices.

The business world of the industrial world who is a partner of SMK Negeri 1 OKU through cooperation in implementing industrial work practices provides benefits for both parties. However, further analysis of the achievement of goals with the involvement of the business world and industry is needed so that the expected results are more targeted and efficient.

\section{References}

Salinan Undang-undang Sistem Pendidikan Nasional Nomor 20 Tahun 2003. Tersedia pada 
https://pusdiklat.perpusnas.go.id/public/media/regulasi/2019/11/12/2019_11_12-

03_49_06_9ab7e1fa524ba603bc2cdbeb7bff93c3.pdf

Suryadi, 2010. "Permasalahan dan Alternatif Kebijakan Peningkata Relevansi Pendidikan (Studi Relevansi Pendidikan Kerjasama UPI Dengan Balitbang

Sumarno. 2008. Employability Skill dan Pengaruhnya terhadap Pengahasilan Lulusan SMK Teknologi dan Industri, Jurnal Kependidikan Lembaga Penelitian UNY. Tahun XXXVIII. Nomor 1. Mei 2008. Yogyakarta: LLPM UNY

Mulyasa, E. 2005. Manajemen Berbasis Sekolah. Bandung: Remaja Rosdakarya.

Peraturan Menteri Tenaga Kerja dan Transmigrasi Republik Indonesia Nomor: PER.21/MEN/X/2007 tentang Standar Kompetensi Kerja Nasional Indonesia. Tersedia pada jdih.kemenperin.go.id. 